\title{
Life threatening shrimp allergy cross reacting with mite allergy : a case report
}

\author{
Farag I Farag-Mahmod ${ }^{1,2^{*}}$, Waheed I Hessam ${ }^{1}$ \\ From Canadian Society of Allergy and Clinical Immunology Annual Scientific Meeting 2013 \\ Toronto, Canada. 3-6 October 2013
}

\section{Background}

Food allergy is apparently increasing and it is estimated that $3-4 \%$ of adults have food allergy. Shrimp is one of the most common causatives in seafood allergy. Patients with shrimp allergy may exhibit life threatening anaphylactic reactions. Tropomyosin is a known important allergen in shrimp. The IgE-binding epitope in shrimp tropomyosin, cross-reacts with other allergenic invertebrate tropomyosins in house dust mites (Der p 10, Der f 10) and cockroaches (Per a 7).

\section{Objective}

This study was undertaken to evaluate the results of immunotherapy to Mites upon allergic reactions to shrimp allergen in a 40 years old female suffering from combined allergy to mites and shrimp. The patient had a 10 years history of severe allergic reactions after eating shrimp; for which she was hospitalized several times to receive intravenous steroids and antihistamines. Despite avoiding consumption of shrimp for several years she continued to have allergic rhinitis symptoms. The last episode of allergic reactions to shrimp occurred while cooking shrimp not eating it.

\section{Materials and methods}

Allergy skin prick testing against a panel of 30 common allergens including Mites and shrimp ( Omega, Montreal, Canada) revealed a strong positive wheal and erythema reaction to both shrimp and $\mathrm{D}$. farinae $(13 \mathrm{~mm}, 9 \mathrm{~mm}$ for wheal and $2.5 \mathrm{~cm}, 2.3 \mathrm{~cm}$ for erythema respectively). Allergen specific serum IgE testing also revealed elevated serum specific IgE to both allergens. The patient started subcutaneous allergen specific immunotherapy (ASIT)

\footnotetext{
* Correspondence: ffarag112@yahoo.com

${ }^{1}$ Suez Canal University Hospital, Faculty of Medicine, Allergy \& Immunology Unit, Egypt

Full list of author information is available at the end of the article
}

against D. farinae using Omega labs allergy shots. Six months after ASIT there was a significant reduction in the size of the wheal and erythema and also significant decrease of serum specific IgE values for both allergens.

\section{Conclusion}

Subcutaneous immunotherapy against mites may desensitize patients against shrimp allergy.

\section{Authors' details \\ ${ }^{1}$ Suez Canal University Hospital, Faculty of Medicine, Allergy \& Immunology Unit, Egypt. ²Omega laboratories Ltd, Montreal, Quebec, Canada.}

Published: 3 March 2014

doi:10.1186/1710-1492-10-S1-A9

Cite this article as: Farag-Mahmod and Hessam: Life threatening shrimp allergy cross reacting with mite allergy : a case report. Allergy, Asthma \& Clinical Immunology 2014 10(Suppl 1):A9.

\section{Submit your next manuscript to BioMed Central and take full advantage of: \\ - Convenient online submission \\ - Thorough peer review \\ - No space constraints or color figure charges \\ - Immediate publication on acceptance \\ - Inclusion in PubMed, CAS, Scopus and Google Scholar \\ - Research which is freely available for redistribution

